\title{
ASOSIASI GASTROPODA DENGAN TUMBUHAN MANGROVE PADA EKOSISTEM PANTAI DI NEGERI TIOUW DAN NEGERI HARIA KECAMATAN SAPARAUA KABUPATEN MALUKU TENGAH
}

\author{
Linus Takandare', P.M. Papilaya² \\ ${ }^{1}$ Alumni Program Studi Pendidikan Biologi \\ 2Dosen Program Studi Pendidikan Biologi \\ E-mail: joyfullpamela@yahoo.co.id
}

\begin{abstract}
Background: Mangrove forests are one of the unique natural ecosystems with high ecological value. Mangrove ecosystems are one of the areas with high productivity because there are litter and decomposition of litter and detritus occurs. This study was conducted to determine the association between gastropods and mangrove plants.

Method: Research on gastropod association with mangrove plants in the coastal waters of Tiouw Village and Haria Village was conducted in January 2018.

Results: This study found from gastropods 6 species namely variabilis strombus, microurceus strombus, Nassarius luridus, Strombus urceus, Cypraea annulus, Strombus, Strombus, Nerita squamulata. From the mangrove plants, 10 species were found: Avicennia eucalyptifolia, Avicennia lanata, Bruguiera sexangula, Rhizophora apiculata, Bruguiera hainessi, Aegiceras floridum R, Aegiceras curniculatum L, Bruguiera palviflora, Bruguiera exaristafa, Ceriops tagal.

Conclusion: Association values ranged from 0.741-0.9773 with positive and negative types. This means that both types of seagrass are often found together or not found together in the observation location.
\end{abstract}

Keywords: Mangrove, gastropods, associations

\begin{abstract}
Abstrak
Latar Belakang: Hutan Mangrove merupakan salah satu ekosistem alami yang unik dengan nilai ekologis yang tinggi. Ekosistem mangrove adalah salah satu daerah yang produktivitasnya tinggi karena ada serasah dan terjadi dekomposisi serasah sehingga terdapat detritus. Penelitian ini dilakukan untuk mengetahui asosiasi antar gastropoda dengan tumbuhan mangrove.

Metode: Penelitian tentang asosiasi gastropoda dengan tumbuhan mangrove di perairan pantai Desa Tiouw dan Desa Haria dilaksanakan pada bulan Januari 2018.

Hasil: Penelitian ini menemukan dari kelas gastropoda 6 spesies yaitu Strombus variabilis, Strombus microurceus, Nassarius luridus, Strombus urceus, Cypraea annulus, Strombus, Strombus, Nerita squamulata. Dari tumbuhan mangrove ditemukan 10 spesies yaitu Avicennia eucalyptifolia, Avicennia lanata, Bruguiera sexangula, Rhizophora apiculata, Bruguiera hainessi, Aegiceras floridum R, Aegiceras curniculatum L, Bruguiera palviflora, Bruguiera exaristafa, Ceriops tagal.

Kesimpulan: Nilai asosiasi berkisar antara 0,741-0,9773 dengan tipe positif dan negatif. Hal ini berarti kedua jenis lamun tersebut sering ditemukan bersama-sama atau tidak ditemukan bersama dalam lokasi pengamatan.
\end{abstract}

Kata Kunci: Mangrove, gastropoda, asosiasi. 


\section{PENDAHULUAN}

Hutan Mangrove merupakan salah satu ekosistem alamiah yang unik dengan nilai ekologis yang tinggi. Ekosistem mangrove adalah salah satu daerah yang produktifitasnya tinggi karena ada serasah dan terjadi dekomposisi serasah sehingga terdapat detritus (Suwondo, dkk, 2004). Ekosistem mangrove memiliki banyak fungsi, baik secara ekologis maupun ekonomis. Salah satu fungsi ekologisnya yaitu merupakan habitat dari berbagai jenis biota laut, termasuk biota penempel. Biota penempel yang terdapat pada berbagai bagian (daun, rizosfer dan anakan) dari vegetasi mangrove.

Ekosistem mangrove merupakan ekosistem yang dipengaruhi oleh kondisi perairan yang berubah setiap saat.Hal ini memberikan pengaruh terhadap biota perairan yang hidup berasosiasi dengan ekosistem mangrove tersebut. Yuniarti (2007) menyatakan bahwa wilayah pesisir merupakan lingkungan bahari yang produktif yang dapat dimanfaatkan secara langsung maupun tidak langsung. Menurut (Supriharyono 2000), Hutan mangrove disebut pula dengan hutan bakau atau hutan payau.
Rochana E (2006), penyebutan mangrove sebagai hutan bakau nampaknya kurang tepat karena bakau merupakan salah satu nama kelompok jenis tumbuhan yang ada di mangrove. Gastropoda merupakan anggota moluska yang sebagian besar bercangkang selain sebagai salah satu komponen yang penting dalam rantai makanan, beberapa jenis gastropoda juga merupakan keong yang bernilai ekonomis tinggi karena cangkangnnya diambil sebagai bahan untuk perhiasan dan cendramata, sepertih beberapa jenis keong dari suku strombidae, cypraeidae, olividae, conidae, trochidae dan toniidae (Saripantung, 2013). Dharma (1988), Gastropoda umumnya hidup di laut tetapiada sebagian yang hidup di darat. Gastropoda mempunyai peranan yang penting baik dari segi ekologi maupun ekonomi.

\section{MATERI DAN METODE}

Berdasarkan data yang telah diperoleh di lokasi penelitian, maka data asosiasi antar jenis dapat diperoleh dengan model seperti dibawah ini.

Tabel 1. Analisis Data Untuk Mengetahui Asosisasi Antara Jenis (Mueller Dumbois dan Ellenberg, 1974).

\begin{tabular}{lccc}
\hline \multicolumn{1}{c}{ Spesies A } & \multicolumn{4}{c}{ Spesies B } \\
\cline { 2 - 4 } & Ada & Tidak Ada & Jumlah \\
\hline Ada & $\mathrm{A}$ & $\mathrm{b}$ & $\mathrm{m}=\mathrm{a}+\mathrm{b}$ \\
Tidak Ada & $\mathrm{C}$ & $\mathrm{d}$ & $\mathrm{n}=\mathrm{c}+\mathrm{d}$ \\
Jumlah & $\mathrm{r}=\mathrm{a}+\mathrm{c}$ & $\mathrm{s}=\mathrm{b}+\mathrm{d}$ & $\mathrm{N}=\mathrm{a}+\mathrm{b}+\mathrm{c}+\mathrm{d}$ \\
\hline
\end{tabular}

Keterangan: $\mathrm{a}=$ jumlah plot yang terdapat spesies $\mathrm{A}$ dan $\mathrm{B}$ bersama-sama. $\mathrm{b}=$ jumlah plot yang terdapat spesies $A$ tetapi spesies $B$ tidak. $C=$ jumlah plot yang terdapat spesies $B$ tetapi spesies $A$ tidak. $d=$ jumlah plot yang tidak terdapat baik spesies $A$ juga spesies $B . N=$ jumlah total plot (petak pengamatan).

mnrs $=(a+b)(c+d)(a+c)(b+d)$

$\left(\mathrm{X}^{2}\right)$ hitung $=\frac{\mathrm{N}(a d-b c)^{2}}{(\mathrm{a}+\mathrm{b})(a+c)(c+d)(b+d)}$

Untuk mngetahui asosiasi tersebut bersifat positif atau negatif digunakan rumus, (Ludwig and Reynolds. 1988) sebgai berikut:

$E(a)=\frac{\mathrm{rm}}{\mathrm{N}} \frac{(\mathrm{a}+\mathrm{c})(a+b)}{\mathrm{N}}$
Keterangan:

$E(a)$ = nilai yang diharapkan untuk seluruh a

$A=$ pengamatan jumlah titik pengukuran yang mengandung spesies $A$ dan $B$

$B=$ pengamatan jumlah titik pengukuran yang mengandung spesies A saja

$\mathrm{C}=$ pengamatan jumlah titik pengukuran yang mengandung spesies $B$ saja

$D=$ pengamatan jumlah titik pengukuran yang tidak mengandung $A$ dan $B$

$\mathrm{N}=$ jumlah titik pengukuran 
Asosiasi positif, apa bila a $>E(a)$ berarti pasangan spesies terjadi bersama lebih sering dari yang diharapkan. Asosiasi negatif apa bila a $<\mathrm{E}$ (a) berarti pasangan spesies terjadi bersama lebih kurang sering yang diharapkan.

Menurut (Ludwig and Reynolds. 1988), ukuran untuk mendapatkan asosisasi yaitu indeks Ochiai, indeks ini cenderung bernilai 0 saat tidak ada asosiasi dan bernilai 1 saat asosiasi maksimum.Ukuran Ochiai menggunakan rasio $\mathrm{a} / \mathrm{m}$ dan $\mathrm{a} / \mathrm{r}$ yaitu nilai dari tingkat kemunculan 2 spesies dibandingkan dengan kemunculan total spesies A dan B. Indeks Ochiai (OI) dijelaskan dalam ratarata geometrik $\mathrm{a} / \mathrm{m}$ dan $\mathrm{a} / \mathrm{r}$ yaitu:
$\mathrm{OI}=\frac{a}{\sqrt{a+b} \sqrt{a+c}}$

$a=$ jumlah plot ditemukannya kedua jenis (A dan B)

$\mathrm{b}=$ jumlah plot ditemukannya jenis $\mathrm{A}$ tetapi tidak jenis $B$

$\mathrm{C}=$ jumlah plot ditemukannya jenis $\mathrm{B}$ tetapi tidak jenis $A$

Asosiasi terjadi pada selang nilai $0-1$, semakin mendekati angka 1 maka semakin kuat hubungan kedua jenis tersebut, demikian pula sebaliknya.

\section{HASIL DAN PEMBAHASAN}

Berdasarkan proses penelitian yang dilkukan maka diperoleh parameter lingkungan pada setiap stasiun penelitian sebagai berikut :

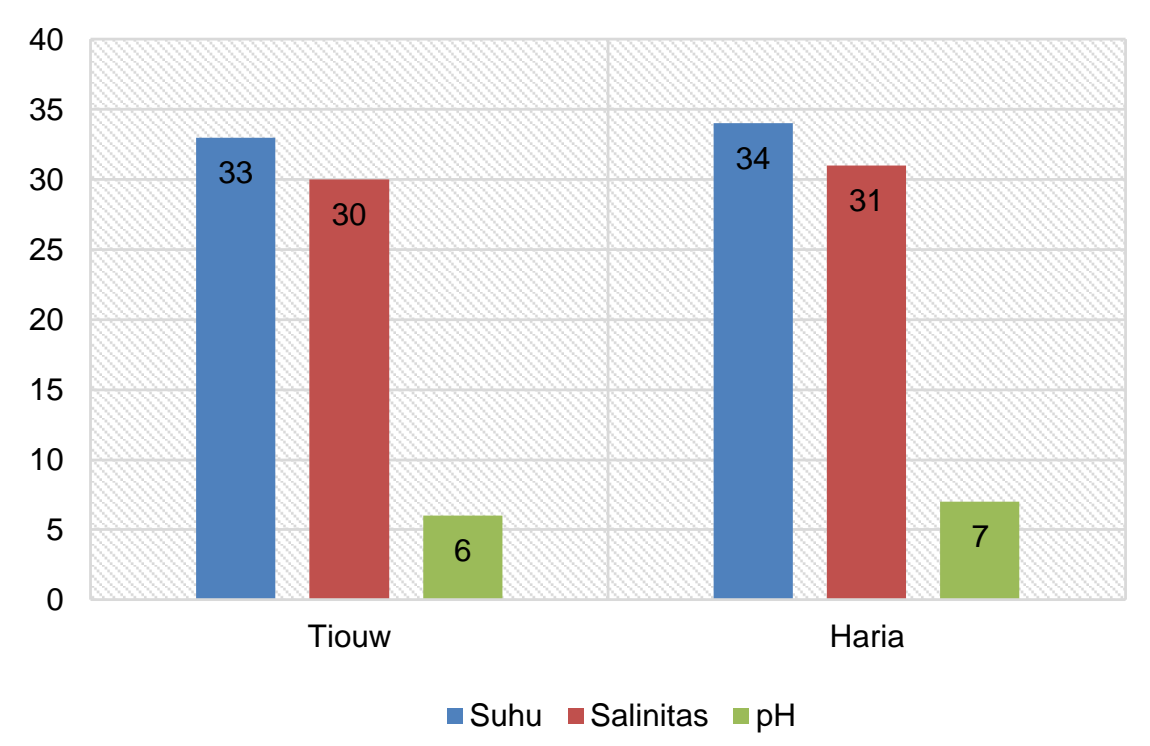

Gambar 1. Grafik Pengukuran Parameter Lingkungan

Suhu perairan dikawasan perairan pantai Desa Tiouw dan Desa Haria berbeda, untuk Desa Tiouw berkisar ratarata $33^{\circ} \mathrm{C}$, dan Desa Haria suhu berkisar rata-rata $34^{\circ} \mathrm{C}$ dimana suhu terendah terdapat pada stasiun I pada Desa Tiouw. Untuk kandungan salinitas pada stasiun I Desa Tiouw memiliki kandungan salinitas 30 ppt, untuk stasiun II Desa Haria dengan salinitas yang tinggi yaitu 31 ppt.

\begin{abstract}
Asosiasi antara gastropoda dengan tumbuhan mangrove diuji dengan menggunakan metode $2 \times 2$ Contingensi Table. Untuk mengetahui adanya kecenderungan untuk berasosiasi atau tidak dipergunakan dengan nilai Chi-Square test, kemudian hasilnya di bandingkan dengan Chi-Square Table pada derajat bebas $=1$ dengan taraf uji $5 \%$.
\end{abstract}


Tabel 2. Hasil Perhitungan Kecenderungan Asosiasi Gastropoda Dengan Tumbuhan Mangrove Pada Ekosistem Pantai Di Negri Tiouw Dan Negri Haria Kecamatan Saparua.

\begin{tabular}{|c|c|c|c|c|c|c|c|c|c|c|}
\hline No & $\begin{array}{l}\text { Pasangan } \\
\text { Spesies (1) }\end{array}$ & $\begin{array}{l}N \\
(2)\end{array}$ & $\begin{array}{l}\text { ad } \\
(3)\end{array}$ & $\begin{array}{l}\text { bc } \\
(4)\end{array}$ & $\begin{array}{l}\text { ad- } \\
\text { bc } \\
\text { (5) }\end{array}$ & $\begin{array}{l}\text { (ad- } \\
\text { bc) } \\
(6)\end{array}$ & $(2) \times(6)$ & mnrs & $\mathrm{X}^{2}$ & $\begin{array}{c}X^{2} \\
\text { Tab }\end{array}$ \\
\hline 1. & $\begin{array}{l}\text { Strombus } \\
\text { variabilis- } \\
\text { Avicennia } \\
\text { eucalyptifolia }\end{array}$ & 20 & 42 & 0 & 42 & 1764 & 35280 & 4284 & 8,23 & 3,84 \\
\hline 2. & $\begin{array}{l}\text { Strombus } \\
\text { variabilis- } \\
\text { Avicennia lanata }\end{array}$ & 20 & 34 & 0 & 34 & 1156 & 23120 & 1836 & 12,59 & 3,84 \\
\hline 3. & $\begin{array}{l}\text { Strombus } \\
\text { variabilis- } \\
\text { Aegiceras } \\
\text { curniculatum L }\end{array}$ & 20 & 24 & 5 & 19 & 361 & 7220 & 4641 & 1,55 & 3,84 \\
\hline 4. & $\begin{array}{l}\text { Strombus } \\
\text { variabilis- } \\
\text { Aegiceras } \\
\text { floridum } R\end{array}$ & 20 & 0 & 6 & -6 & 36 & 720 & 18360 & 0,39 & 3,84 \\
\hline 5. & $\begin{array}{l}\text { Strombus } \\
\text { variabilis- } \\
\text { Bruguiera } \\
\text { sexangular }\end{array}$ & 20 & 0 & 0 & 0 & 0 & 0 & 0 & 0 & 3,84 \\
\hline 6. & $\begin{array}{l}\text { Strombus } \\
\text { variabilis- } \\
\text { Bruguiera } \\
\text { hainessi }\end{array}$ & 20 & 0 & 0 & 0 & 0 & 0 & 0 & 0 & 3,84 \\
\hline 7. & $\begin{array}{l}\text { Strombus } \\
\text { variabilis- } \\
\text { Bruguiera } \\
\text { palviflora }\end{array}$ & 20 & 0 & 0 & 0 & 0 & 0 & 0 & 0 & 3,84 \\
\hline 8. & $\begin{array}{l}\text { Strombus } \\
\text { variabilis- } \\
\text { Rhizophora } \\
\text { apiculate }\end{array}$ & 20 & 0 & 0 & 0 & 0 & 0 & 0 & 0 & 3,84 \\
\hline 9. & $\begin{array}{l}\text { Strombus } \\
\text { variabilis- Ceriops } \\
\text { tagal }\end{array}$ & 20 & 0 & 0 & 0 & 0 & 0 & 0 & 0 & 3,84 \\
\hline 10. & $\begin{array}{l}\text { Strombus } \\
\text { variabilis- } \\
\text { Bruguiera } \\
\text { exaristafa }\end{array}$ & 20 & 0 & 0 & 0 & 0 & 0 & 0 & 0 & 3,84 \\
\hline 11. & $\begin{array}{l}\text { Strombus } \\
\text { microurceus- } \\
\text { Avicennia } \\
\text { eucalyptifolia }\end{array}$ & 20 & 0 & 0 & 0 & 0 & 0 & 0 & 0 & 3,84 \\
\hline 12. & $\begin{array}{l}\text { Strombus } \\
\text { microurceus- } \\
\text { Avicennia lanata }\end{array}$ & 20 & 0 & 0 & 0 & 0 & 0 & 0 & 0 & 3,84 \\
\hline 13. & $\begin{array}{l}\text { Strombus } \\
\text { microurceus- } \\
\text { Aegiceras } \\
\text { curniculatum L }\end{array}$ & 20 & 0 & 0 & 0 & 0 & 0 & 0 & 0 & 3,84 \\
\hline 14 & $\begin{array}{l}\text { Strombus } \\
\text { microurceus- } \\
\text { Aegiceras } \\
\text { floridum } R \\
\end{array}$ & 20 & 0 & 0 & 0 & 0 & 0 & 0 & 0 & \\
\hline
\end{tabular}




\begin{tabular}{|c|c|c|c|c|c|c|c|c|c|c|}
\hline 15. & $\begin{array}{l}\text { Strombus } \\
\text { microurceus- } \\
\text { Bruguiera } \\
\text { sexangular }\end{array}$ & 20 & 0 & 0 & 0 & 0 & 0 & 0 & 0 & 3,84 \\
\hline 16. & $\begin{array}{l}\text { Strombus } \\
\text { microurceus- } \\
\text { Bruguiera } \\
\text { hainessi }\end{array}$ & 20 & 0 & 0 & 0 & 0 & 0 & 0 & 0 & 3,84 \\
\hline 17. & $\begin{array}{l}\text { Strombus } \\
\text { microurceus- } \\
\text { Bruguiera } \\
\text { palviflora }\end{array}$ & 20 & 0 & 0 & 0 & 0 & 0 & 0 & 0 & 3,84 \\
\hline 18. & $\begin{array}{l}\text { Strombus } \\
\text { microurceus- } \\
\text { Rhizophora } \\
\text { apiculate }\end{array}$ & 20 & 0 & 0 & 0 & 0 & 0 & 0 & 0 & 3,84 \\
\hline 19. & $\begin{array}{l}\text { Strombus } \\
\text { microurceus- } \\
\text { Ceriops tagal }\end{array}$ & 20 & 0 & 0 & 0 & 0 & 0 & 0 & 0 & 3,84 \\
\hline 20. & $\begin{array}{l}\text { Strombus } \\
\text { microurceus } \\
\text { Bruguiera } \\
\text { exaristafa }\end{array}$ & 20 & 0 & 0 & 0 & 0 & 0 & 0 & 0 & 3,84 \\
\hline 21. & $\begin{array}{l}\text { Nassarius luridus } \\
\text {-Avicennia } \\
\text { eucalyptifolia }\end{array}$ & 20 & 0 & 0 & 0 & 0 & 0 & 0 & 0 & 3,84 \\
\hline 22. & $\begin{array}{l}\text { Nassarius luridus } \\
\text { - Avicennia lanata }\end{array}$ & 20 & 0 & 0 & 0 & 0 & 0 & 0 & 0 & 3,84 \\
\hline 23. & $\begin{array}{l}\text { Nassarius luridus } \\
-\quad \text { Aegiceras } \\
\text { curniculatum L }\end{array}$ & 20 & 0 & 0 & 0 & 0 & 0 & 0 & 0 & 3,84 \\
\hline 24. & $\begin{array}{l}\text { Nassarius luridus } \\
-\quad \text { Aegiceras } \\
\text { floridum } R\end{array}$ & 20 & 0 & 0 & 0 & 0 & 0 & 0 & 0 & 3,84 \\
\hline 25. & $\begin{array}{l}\text { Nassarius luridus } \\
-\quad \text { Bruguiera } \\
\text { sexangular }\end{array}$ & 20 & 0 & 0 & 0 & 0 & 0 & 0 & 0 & 3,84 \\
\hline 26. & $\begin{array}{l}\text { Nassarius luridus } \\
-\quad \text { Bruguiera } \\
\text { hainessi }\end{array}$ & 20 & 0 & 0 & 0 & 0 & 0 & 0 & 0 & 3,84 \\
\hline 27. & $\begin{array}{l}\text { Nassarius luridus } \\
-\quad \text { Bruguiera } \\
\text { palviflora }\end{array}$ & 20 & 0 & 0 & 0 & 0 & 0 & 0 & 0 & 3,84 \\
\hline 28. & $\begin{array}{l}\text { Nassarius luridus } \\
-\quad \text { Rhizophora } \\
\text { apiculate }\end{array}$ & 20 & 0 & 0 & 0 & 0 & 0 & 0 & 0 & 3,84 \\
\hline 29. & $\begin{array}{l}\text { Nassarius luridus } \\
\text { - Ceriops taga }\end{array}$ & 20 & 0 & 0 & 0 & 0 & 0 & 0 & 0 & 3,84 \\
\hline 30. & $\begin{array}{l}\text { Nassarius luridus } \\
-\quad \text { Bruguiera } \\
\text { exaristafa }\end{array}$ & 20 & 0 & 0 & 0 & 0 & 0 & 0 & 0 & 3,84 \\
\hline 31. & $\begin{array}{l}\text { Strombus urceus } \\
\text {-Avicennia } \\
\text { eucalyptifolia }\end{array}$ & 20 & 22 & 12 & 10 & 100 & 2000 & 6300 & 0,31 & 3,84 \\
\hline 32. & $\begin{array}{l}\text { Strombus urceus } \\
\text { - Avicennia lanata }\end{array}$ & 20 & 0 & 10 & -10 & 100 & 2000 & 2700 & 0,74 & 3,84 \\
\hline 33. & $\begin{array}{l}\text { Strombus urceus } \\
-\quad \text { Aegiceras } \\
\text { curniculatum } L\end{array}$ & 20 & 33 & 6 & 27 & 729 & 14580 & 6825 & 2,13 & 3,84 \\
\hline
\end{tabular}




\begin{tabular}{|c|c|c|c|c|c|c|c|c|c|c|}
\hline 34. & $\begin{array}{l}\text { Strombus urceus } \\
-\quad \text { Aegiceras } \\
\text { floridum } R\end{array}$ & 20 & 30 & 0 & 30 & 900 & 18000 & 2700 & 6,66 & 3,84 \\
\hline 35. & $\begin{array}{l}\text { Strombus urceus } \\
-\quad \text { Bruguiera } \\
\text { sexangular }\end{array}$ & 20 & 0 & 10 & -10 & 100 & 2000 & 2700 & 0,74 & 3,84 \\
\hline 36. & $\begin{array}{l}\text { Strombus urceus } \\
-\quad \text { Bruguiera } \\
\text { hainessi }\end{array}$ & 20 & 33 & 8 & 25 & 625 & 12500 & 6825 & 1,83 & 3,84 \\
\hline 37. & $\begin{array}{l}\text { Strombus urceus } \\
-\quad \text { Bruguiera } \\
\text { palviflora }\end{array}$ & 20 & 22 & 12 & 10 & 100 & 2000 & 6300 & 0,31 & 3,84 \\
\hline 38. & $\begin{array}{l}\text { Strombus urceus } \\
-\quad \text { Rhizophora } \\
\text { apiculate }\end{array}$ & 20 & 0 & 10 & -10 & 100 & 2000 & 2700 & 0,74 & 3,84 \\
\hline 39. & $\begin{array}{l}\text { Strombus urceus } \\
\text { - Ceriops taga }\end{array}$ & 20 & 30 & 0 & 30 & 900 & 18000 & 2700 & 6,66 & 3,84 \\
\hline 40. & $\begin{array}{l}\text { Strombus urceus } \\
-\quad \text { Bruguiera } \\
\text { exaristafa }\end{array}$ & 20 & 33 & 8 & 25 & 625 & 12500 & 6825 & 1,83 & 3,84 \\
\hline 41. & $\begin{array}{l}\text { Cypraea annulu- } \\
\text { Avicennia } \\
\text { eucalyptifolia }\end{array}$ & 20 & 52 & 2 & 50 & 2500 & 50000 & 6300 & 7,93 & 3,84 \\
\hline 42. & $\begin{array}{l}\text { Cypraea annulu- } \\
\text { Avicennia lanata }\end{array}$ & 20 & 14 & 4 & 10 & 100 & 2000 & 2700 & 0,74 & 3,84 \\
\hline 43. & $\begin{array}{l}\text { Cypraea annulu- } \\
\text { Aegiceras } \\
\text { curniculatum L }\end{array}$ & 20 & 48 & 3 & 45 & 2025 & 40500 & 6300 & 6,42 & 3,84 \\
\hline 44. & $\begin{array}{l}\text { Cypraea annulu- } \\
\text { Aegiceras } \\
\text { floridum } R\end{array}$ & 20 & 0 & 10 & -10 & 100 & 2000 & 2700 & 0,74 & 3,84 \\
\hline 45. & $\begin{array}{l}\text { Cypraea annulu- } \\
\text { Bruguiera } \\
\text { sexangular }\end{array}$ & 20 & 52 & 2 & 50 & 2500 & 50000 & 6825 & 7,32 & 3,84 \\
\hline 46. & $\begin{array}{l}\text { Cypraea annulu- } \\
\text { Bruguiera } \\
\text { hainessi }\end{array}$ & 20 & 14 & 4 & 10 & 100 & 2000 & 2700 & 0,74 & 3,84 \\
\hline 47. & $\begin{array}{l}\text { Cypraea annulu- } \\
\text { Bruguiera } \\
\text { palviflora }\end{array}$ & 20 & 14 & 4 & 10 & 100 & 200 & 2700 & 0,74 & 3,84 \\
\hline 48. & $\begin{array}{l}\text { Cypraea annulu- } \\
\text { Rhizophora } \\
\text { apiculate }\end{array}$ & 20 & 68 & 2 & 66 & 4356 & 87120 & 6300 & 13,82 & 3,84 \\
\hline 49. & $\begin{array}{l}\text { Cypraea annulu- } \\
\text { Ceriops taga }\end{array}$ & 20 & 68 & 2 & 66 & 4356 & 87120 & 6300 & 13,82 & 3,84 \\
\hline 50. & $\begin{array}{l}\text { Cypraea annulu- } \\
\text { Bruguiera } \\
\text { exaristafa }\end{array}$ & 20 & 14 & 4 & 10 & 100 & 2000 & 2700 & 0,74 & 3,84 \\
\hline 51. & $\begin{array}{l}\text { Nerita squamulata } \\
\text {-Avicennia } \\
\text { eucalyptifolia }\end{array}$ & 20 & 12 & 10 & 2 & 4 & 80 & 4284 & 0,01 & 3,84 \\
\hline 52. & $\begin{array}{l}\text { Nerita squamulata } \\
\text { - Avicennia lanata }\end{array}$ & 20 & 16 & 2 & 14 & 196 & 3920 & 1836 & 2,13 & 3,84 \\
\hline 53. & $\begin{array}{l}\text { Nerita squamulata } \\
-\quad \text { Aegiceras } \\
\text { curniculatum } L\end{array}$ & 20 & 0 & 12 & -12 & 144 & 2880 & 3264 & 0,88 & 3,84 \\
\hline 54. & $\begin{array}{r}\text { Nerita squamulata } \\
-\quad \text { Aegiceras }\end{array}$ & 20 & 0 & 6 & -6 & 36 & 720 & 1836 & 0,39 & 3,84 \\
\hline
\end{tabular}




\begin{tabular}{|c|c|c|c|c|c|c|c|c|c|c|}
\hline & floridum $R$ & & & & & & & & & \\
\hline 55. & $\begin{array}{l}\text { Nerita squamulata } \\
-\quad \text { Bruguiera } \\
\text { sexanqular }\end{array}$ & 20 & 33 & 9 & 24 & 576 & 11520 & 7056 & 1,63 & 3,84 \\
\hline 56. & $\begin{array}{l}\text { Nerita squamulata } \\
-\quad \text { Bruguiera } \\
\text { hainessi }\end{array}$ & 20 & 0 & 12 & -12 & 144 & 2880 & 3024 & 0,95 & 3,84 \\
\hline 57. & $\begin{array}{l}\text { Nerita squamulata } \\
\text { - } \quad \text { Bruguiera } \\
\text { palviflora }\end{array}$ & 20 & 44 & 6 & 38 & 1444 & 28880 & 7644 & 3,77 & 3,84 \\
\hline 58. & $\begin{array}{l}\text { Nerita squamulata } \\
-\quad \text { Rhizophora } \\
\text { apiculate }\end{array}$ & 20 & 0 & 12 & -12 & 144 & 2880 & 3024 & 0,95 & 3,84 \\
\hline 59. & $\begin{array}{l}\text { Nerita squamulata } \\
\text { - Ceriops taga }\end{array}$ & 20 & 30 & 12 & 18 & 324 & 6480 & 7644 & 0,84 & 3,84 \\
\hline 60. & $\begin{array}{l}\text { Nerita squamulata } \\
-\quad \text { Bruguiera } \\
\text { exaristafa }\end{array}$ & 20 & 0 & 14 & -14 & 196 & 3920 & 3276 & 1,19 & 3,84 \\
\hline
\end{tabular}

Keterangan: $\mathrm{a}=$ jumlah plot yang terdapat spesies $\mathrm{A}$ dan $\mathrm{B}$ bersama-sama. $\mathrm{b}=$ jumlah plot yang terdapat spesies $A$ tetapi spesies $B$ tidak. $c=$ jumlah plot yang terdapat spesies $B$ tetapi spesies $A$ tidak. $d=$ jumlah plot yang tidak terdapat baik spesies $A$ juga spesies $B . N=$ jumlah total plot (petak pengamatan). $X^{2}=$ Chi-Square hitung. $X^{2}$ tab $=$ Chi-Square tab. mnrs $=(a+b)(c+d)(a+c)(b+d)$.

Berdasarkan tabel dapat dilihat bahwa 51 pasangan spesies tersebut mengadakan asosiasi tidak nyata pada taraf $5 \%$, dikarenakan nilai Chi-Square hitung lebih kecil dari nilai Chi-Square table. Sedangkan, 9 spesies yang lain mengadakan nilai asosiasi nyata pada taraf uji tersebut, dikarenakan nilai Ch-Squqre hitung lebih besar dari nilai Chi-Square tabel, yaitu pasangan Strombus variabilisAvicennia eucalyptifolia, Strombus variabilis-Avicennia lanata, Strombus urceus-Aegiceras floridum $R$, Strombus urceus-Ceriops taga, Cypraea annuluAvicennia eucalyptifolia, Cypraea annuluAegiceras curniculatum L,CypraeaannuluBruguiera sexangular, Cypraea annuluRhizophora apiculate, Cypraea annuluCeriops ta.
Asosiasi merupakan suatu abstraksi berdasarkan totalitas dari jenis-jenis yang homogen dan secara floristik berhubungan erat satu sama lain.(Whittaker. 1975), menyebutkan bahwa asosiasi positif berarti secara tidak langsung beberapa jenis berhubungan baik atau ketergantungan antara satu dengan yang lainnya, sedangkan asosiasi negatif berarti secara tidak langsung beberapa jenis mempunyai kecenderungan untuk meniadakan atau mengeluarkan yang lainnya atau juga berarti dua jenis mempunyai pengaruh atau reaksi yang berbeda dalam lingkungannya. Analisis asosiasi adalah pengelompokan yang bertujuan untuk mengurangi keanekragaman. Suatu kelompok spesies dikatakan beranekaragam jika ada pasangan spesies yang asosiasinya signifikan. 
Tabel 3. Hasil Perhitungan Analisis Asosiasi Gastropoda Dengan Tumbuhan Mangrove Pada Ekosistem Pantai Di Negri Tiouw Dan Negri Haria Kecamatan Saparua.

\begin{tabular}{|c|c|c|c|c|c|c|c|}
\hline No & Pasangan Spesies & A & $a+c$ & $a+b$ & $\mathrm{~N}$ & $E(a)$ & Asosiasi \\
\hline 1. & $\begin{array}{l}\text { Strombus variabilis- Avicennia } \\
\text { eucalyptifolia }\end{array}$ & 14 & 14 & 17 & 20 & 11,9 & Positif \\
\hline 2. & $\begin{array}{l}\text { Strombus variabilis- Avicennia } \\
\text { lanata }\end{array}$ & 17 & 18 & 17 & 20 & 15,3 & Positif \\
\hline 3. & $\begin{array}{l}\text { Strombus variabilis- Aegiceras } \\
\text { curniculatum } L\end{array}$ & 12 & 13 & 17 & 20 & 11,05 & Positif \\
\hline 4. & $\begin{array}{l}\text { Strombus variabilis- Aegiceras } \\
\text { floridum } R\end{array}$ & 15 & 18 & 17 & 20 & 15,3 & Negatif \\
\hline 5. & $\begin{array}{l}\text { Strombus variabilis- Bruguiera } \\
\text { sexangular }\end{array}$ & 14 & 14 & 20 & 20 & 14 & Positif \\
\hline 6. & $\begin{array}{l}\text { Strombus variabilis- Bruguiera } \\
\text { hainessi }\end{array}$ & 18 & 18 & 20 & 20 & 18 & Positif \\
\hline 7. & $\begin{array}{l}\text { Strombus variabilis- Bruguiera } \\
\text { palviflora }\end{array}$ & 13 & 13 & 20 & 20 & 13 & Positif \\
\hline 8. & $\begin{array}{l}\text { Strombus variabilis- Rhizophora } \\
\text { apiculate }\end{array}$ & 18 & 18 & 20 & 20 & 18 & Positif \\
\hline 9. & $\begin{array}{l}\text { Strombus variabilis- Ceriops } \\
\text { tagal }\end{array}$ & 13 & 13 & 20 & 20 & 13 & Positif \\
\hline 10. & $\begin{array}{l}\text { Strombus variabilis- Bruguiera } \\
\text { exaristafa }\end{array}$ & 18 & 18 & 20 & 20 & 18 & Positif \\
\hline 11. & $\begin{array}{l}\text { Strombus microurceus- } \\
\text { Avicennia eucalyptifolia }\end{array}$ & 14 & 14 & 20 & 20 & 14 & Positif \\
\hline 12. & $\begin{array}{l}\text { Strombus microurceus- } \\
\text { Avicennia lanata }\end{array}$ & 18 & 18 & 20 & 20 & 18 & Positif \\
\hline 13. & $\begin{array}{l}\text { Strombus microurceus- } \\
\text { Aegiceras curniculatum } L\end{array}$ & 13 & 13 & 20 & 20 & 13 & Positif \\
\hline 14. & $\begin{array}{l}\text { Strombus microurceus- } \\
\text { Aegiceras floridum } R\end{array}$ & 18 & 18 & 20 & 20 & 18 & Positif \\
\hline 15. & $\begin{array}{l}\text { Strombus microurceus- } \\
\text { Bruguiera sexangular }\end{array}$ & 14 & 14 & 20 & 20 & 14 & Positif \\
\hline 16. & $\begin{array}{l}\text { Strombus microurceus- } \\
\text { Bruguiera hainessi }\end{array}$ & 18 & 18 & 20 & 20 & 18 & Positif \\
\hline 17. & $\begin{array}{l}\text { Strombus microurceus- } \\
\text { Bruguiera palviflora }\end{array}$ & 13 & 13 & 20 & 20 & 13 & Positif \\
\hline 18. & $\begin{array}{l}\text { Strombus microurceus- } \\
\text { Rhizophora apiculate }\end{array}$ & 18 & 18 & 20 & 20 & 18 & Positif \\
\hline 19. & $\begin{array}{l}\text { Strombus microurceus- Ceriops } \\
\text { tagal }\end{array}$ & 13 & 13 & 20 & 20 & 13 & Positif \\
\hline 20 & $\begin{array}{l}\text { Strombus microurceus } \\
\text { Bruguiera exaristafa }\end{array}$ & 18 & 18 & 20 & 20 & 18 & Positif \\
\hline 21. & $\begin{array}{l}\text { Nassarius luridus -Avicennia } \\
\text { eucalyptifolia }\end{array}$ & 14 & 14 & 20 & 20 & 14 & Positif \\
\hline 22. & $\begin{array}{l}\text { Nassarius luridus - Avicennia } \\
\text { lanata }\end{array}$ & 18 & 18 & 20 & 20 & 18 & Positif \\
\hline 23. & $\begin{array}{l}\text { Nassarius luridus - Aegiceras } \\
\text { curniculatum } L\end{array}$ & 13 & 13 & 20 & 20 & 13 & Positif \\
\hline 24. & $\begin{array}{l}\text { Nassarius luridus - Aegiceras } \\
\text { floridum } R\end{array}$ & 18 & 18 & 20 & 20 & 18 & Positif \\
\hline 25. & $\begin{array}{l}\text { Nassarius luridus - Bruguiera } \\
\text { sexangular }\end{array}$ & 13 & 13 & 20 & 20 & 13 & Positif \\
\hline 26. & $\begin{array}{l}\text { Nassarius luridus - Bruguiera } \\
\text { hainessi }\end{array}$ & 18 & 18 & 20 & 20 & 18 & Positif \\
\hline 27. & $\begin{array}{l}\text { Nassarius luridus - Bruguiera } \\
\text { palviflora }\end{array}$ & 14 & 14 & 20 & 20 & 14 & Positif \\
\hline 28. & Nassarius luridus - Rhizophora & 18 & 18 & 20 & 20 & 18 & Positif \\
\hline
\end{tabular}




\begin{tabular}{|c|c|c|c|c|c|c|c|}
\hline & apiculate & & & & & & \\
\hline 29. & Nassarius luridus - Ceriops taga & 13 & 13 & 20 & 20 & 13 & Positif \\
\hline 30. & $\begin{array}{l}\text { Nassarius luridus - Bruguiera } \\
\text { exaristafa }\end{array}$ & 18 & 18 & 20 & 20 & 18 & Positif \\
\hline 31. & $\begin{array}{l}\text { Strombus urceus -Avicennia } \\
\text { eucalyptifolia }\end{array}$ & 11 & 14 & 15 & 20 & 10,5 & Positif \\
\hline 32. & $\begin{array}{l}\text { Strombus urceus - Avicennia } \\
\text { lanata }\end{array}$ & 13 & 18 & 15 & 20 & 13,5 & Negatif \\
\hline 33. & $\begin{array}{l}\text { Strombus urceus - Aegiceras } \\
\text { curniculatum } L\end{array}$ & 11 & 13 & 15 & 20 & 9,75 & Positif \\
\hline 34. & $\begin{array}{l}\text { Strombus urceus - Aegiceras } \\
\text { floridum } R\end{array}$ & 15 & 18 & 15 & 20 & 13,5 & Positif \\
\hline 35. & $\begin{array}{l}\text { Strombus urceus - Bruguiera } \\
\text { sexangular }\end{array}$ & 13 & 18 & 15 & 20 & 13,5 & Negatif \\
\hline 36. & $\begin{array}{l}\text { Strombus urceus - Bruguiera } \\
\text { hainessi }\end{array}$ & 11 & 13 & 15 & 20 & 9,75 & Positif \\
\hline 37. & $\begin{array}{l}\text { Strombus urceus - Bruguiera } \\
\text { palviflora }\end{array}$ & 11 & 145 & 15 & 20 & 10,5 & Positif \\
\hline 38. & $\begin{array}{l}\text { Strombus urceus - Rhizophora } \\
\text { apiculate }\end{array}$ & 13 & 18 & 15 & 20 & 13,5 & Negatif \\
\hline 39. & Strombus urceus - Ceriops taga & 15 & 18 & 15 & 20 & 13,5 & Positif \\
\hline 40. & $\begin{array}{l}\text { Strombus urceus - Bruguiera } \\
\text { exaristafa }\end{array}$ & 11 & 14 & 15 & 20 & 10,5 & Positif \\
\hline 41. & $\begin{array}{l}\text { Cypraea annulu-Avicennia } \\
\text { eucalyptifolia }\end{array}$ & 13 & 14 & 15 & 20 & 10,5 & Positif \\
\hline 42. & $\begin{array}{l}\text { Cypraea annulu- Avicennia } \\
\text { lanata }\end{array}$ & 14 & 18 & 15 & 20 & 13,5 & Positif \\
\hline 43. & $\begin{array}{l}\text { Cypraea annulu- Aegiceras } \\
\text { curniculatum } L\end{array}$ & 12 & 13 & 15 & 20 & 9,75 & Positif \\
\hline 44. & $\begin{array}{l}\text { Cypraea annulu- Aegiceras } \\
\text { floridum } R\end{array}$ & 13 & 18 & 15 & 20 & 13,5 & Negatif \\
\hline 45. & $\begin{array}{l}\text { Cypraea annulu- Bruguiera } \\
\text { sexangular }\end{array}$ & 13 & 14 & 15 & 20 & 10,5 & Positif \\
\hline 46. & $\begin{array}{l}\text { Cypraea annulu- Bruguiera } \\
\text { hainessi }\end{array}$ & 14 & 18 & 15 & 20 & 13,5 & Positif \\
\hline 47. & $\begin{array}{l}\text { Cypraea annulu- Bruguiera } \\
\text { palviflora }\end{array}$ & 14 & 18 & 15 & 20 & 13,5 & Positif \\
\hline 48. & $\begin{array}{l}\text { Cypraea annulu- Rhizophora } \\
\text { apiculate }\end{array}$ & 13 & 14 & 15 & 20 & 10,5 & Positif \\
\hline 49. & Cypraea annulu- Ceriops taga & 13 & 14 & 15 & 20 & 10,5 & Positif \\
\hline 50. & $\begin{array}{l}\text { Cypraea annulu- Bruguiera } \\
\text { exaristafa }\end{array}$ & 14 & 18 & 15 & 20 & 13,5 & Positif \\
\hline 51. & $\begin{array}{l}\text { Nerita squamulata -Avicennia } \\
\text { eucalyptifolia }\end{array}$ & 12 & 14 & 17 & 20 & 11,9 & Positif \\
\hline 52. & $\begin{array}{l}\text { Nerita squamulata - Avicennia } \\
\text { lanata }\end{array}$ & 16 & 18 & 17 & 20 & 15,3 & Positif \\
\hline 53. & $\begin{array}{l}\text { Nerita squamulata - Aegiceras } \\
\text { curniculatum } L\end{array}$ & 13 & 16 & 17 & 20 & 13,6 & Negatif \\
\hline 54. & $\begin{array}{l}\text { Nerita squamulata - Aegiceras } \\
\text { floridum } R\end{array}$ & 15 & 18 & 17 & 20 & 15,3 & Negatif \\
\hline 55. & $\begin{array}{l}\text { Nerita squamulata - Bruguiera } \\
\text { sexangular }\end{array}$ & 11 & 14 & 14 & 20 & 9,8 & Positif \\
\hline 56. & $\begin{array}{l}\text { Nerita squamulata - Bruguiera } \\
\text { hainessi }\end{array}$ & 12 & 18 & 14 & 20 & 12,6 & Negatif \\
\hline 57. & $\begin{array}{l}\text { Nerita squamulata - Bruguiera } \\
\text { palviflora }\end{array}$ & 11 & 13 & 14 & 20 & 9,1 & Positif \\
\hline 58. & $\begin{array}{l}\text { Nerita squamulata - Rhizophora } \\
\text { apiculate }\end{array}$ & 12 & 18 & 14 & 20 & 12,6 & Negatif \\
\hline 59. & $\begin{array}{l}\text { Nerita squamulata - Ceriops } \\
\text { taga }\end{array}$ & 10 & 14 & 13 & 20 & 9,1 & Positif \\
\hline
\end{tabular}




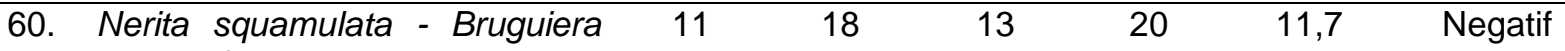
exaristafa

Keterangan: $\mathrm{E}(\mathrm{a})=$ nilai yang diharapkan untuk seluruh $\mathrm{a}$. $\mathrm{a}=$ pengamatan jumlah titik pengukuran yang mengandung spesies $A$ dan $B$. $b=$ pengamatan jumlah titik pengukuran yang mengandung spesies $A$ saja. $C=$ pengamatan jumlah titik pengukuran yang mengandung spesies $B$ saja. $d=$ pengamatan jumlah titik pengukuran yang tidak mengandung spesies Adan $B$. $N=$ jumlah titik pengukuran. Positif $=$ Apabila nilai $a>E(a)$. Negatif $=$ Apabila nilai $a<E(a)$.

Berdasarkan tabel 3. dapat diketahui bahwa dari 60 pasangan spesies yang diuji, terdapat 50 jenis pasangan spesies dengan kejadian bersama antara jenis yang berasosiasi tersebut lebih besar yanag diharapkan. Itu berarti bahwa jenis-jenis pasangan spesies ini mempunyai respon yang sama terhadap perbedaan lingkungan dalam komunitas yang ada pada ekosistem mangrove di Negri Tiouw dan Negri Haria Kecamatan Saparua.

Sedangkan 10 pasangan spesies lainnya mempunyai kejadian bersama antara jenis yang berasosiasi itu lebih kecil dari yang diharapkan.Dengan demikian, jenis-jenis mempunyai respon yang berbeda terhadap adanya perubahan lingkungan dan komunitas tersebut.Selain itu kecenderungan untuk saling mengeluarkan atau meniadakan antara kedua jenis pasangan masing-masing diduga disebabkan oleh terjadinya kompetisi antara masing-masing spesies itu sendiri. Timbulnya kompetisi disebabkan jenis-jenis pasangan spesies tersebut mempunyai kebutuhan hidup yang sama sedangkan sumber-sumber yang mendukung kebutuhan hidup itu sendiri dalam keadaan terbatas. Tingkat kekuatan merupakan suatu lapisan untuk melihat kemampuan ataupun tenaga.Ada satu ukuran untuk mendapatkan kekuatan asosiasi antara Gastropodadengan jenis Mangrove yang ada disekitarnya, yaitu IndeksOchiai (Ludwig dan Reynold. 1988).

Ukuran Indeks Ochiai (OI) dijelaskan dalam rata-rata geometrik $\frac{a}{\mathrm{~m}}$ dan $\frac{a}{\mathrm{r}}$. Indeks ini cenderung bernilai 0 saat tidak ada asosisasi dan bernilai 1 saat asosisasi maksimum.Semakin mendekati angka 1 semakin kuat pula hubungan kedua spesies yang berasosiasi.Dalam penelitian ini indeks asosisasi Gastropoda dengan tumbuhan Mangrove di Negri Tiouw dan Negri Haria Kecamatan Saparua.

\section{Tabel 4. Kekuatan Asosiasi Jenis Mangrove Dan Gastropoda Di Perairan Pantai Desa Tiow Dan Desa Haria Berdasarkan Indeks Ochiai (OI).}

\begin{tabular}{clcl}
\hline No & \multicolumn{1}{c}{ Pasangan Spesies } & OI & Keterangan \\
\hline 1. & Strombus variabilis- Avicennia eucalyptifolia & 0,909 & Asosiasi kuat \\
2. & Strombus variabilis- Avicennia lanata & 0,973 & Asosiasi kuat \\
3. & Strombus variabilis- Aegiceras curniculatum L & 0,807 & Asosiasi kuat \\
4. & Strombus variabilis- Aegiceras floridum $R$ & 0,859 & Asosiasi kuat \\
5. & Strombus variabilis- Bruguiera sexangular & 0,837 & Asosiasi kuat \\
6. & Strombus variabilis- Bruguiera hainessi & 0,949 & Asosiasi kuat \\
7. & Strombus variabilis- Bruguiera palviflora & 0,806 & Asosiasi kuat \\
8. & Strombus variabilis- Rhizophora apiculate & 0,949 & Asosiasi kuat \\
9. & Strombus variabilis- Ceriops tagal & 0,806 & Asosiasi kuat \\
10. & Strombus variabilis- Bruguiera exaristafa & 0,949 & Asosiasi kuat \\
\hline
\end{tabular}


Tabel 5. Kekuatan Asosiasi Jenis Mangrove Dan Gastropoda Di Perairan Pantai Desa Tiow Dan Desa Haria Berdasarkan Indeks Ochiai (OI).

\begin{tabular}{clcc} 
No & \multicolumn{1}{c}{ Pasangan Spesies } & OI & Keterangan \\
1. & Strombus microurceus-Avicennia eucalyptifolia & 0,837 & Asosiasi kuat \\
2. & Strombus microurceus- Avicennia lanata & 0,949 & Asosiasi kuat \\
3. & Strombus microurceus- Aegiceras curniculatum L & 0,806 & Asosiasi kuat \\
4. & Strombus microurceus- Aegiceras floridum $R$ & 0,949 & Asosiasi kuat \\
5. & Strombus microurceus- Bruguiera sexangular & 0,837 & Asosiasi kuat \\
6. & Strombus microurceus- Bruguiera hainessi & 0,949 & Asosiasi kuat \\
7. & Strombus microurceus- Bruguiera palviflora & 0,806 & Asosiasi kuat \\
8. & Strombus microurceus- Rhizophora apiculate & 0,949 & Asosiasi kuat \\
9. & Strombus microurceus- Ceriops tagal & 0,806 & Asosiasi kuat \\
10 & Strombus microurceus - Bruguiera exaristafa & 0,949 & Asosiasi kuat
\end{tabular}

Tabel 6. Kekuatan Asosiasi Jenis Mangrove Dan Gastropoda Di Perairan Pantai Desa Tiow Dan Desa Haria Berdasarkan Indeks Ochiai (OI).

\begin{tabular}{clcl}
\hline No & \multicolumn{1}{c}{ Pasangan Spesies } & Ol & Keterangan \\
\hline 1. & Nassarius luridus -Avicennia eucalyptifolia & 0,837 & Asosiasi kuat \\
2. & Nassarius luridus - Avicennia lanata & 0,949 & Asosiasi kuat \\
3. & Nassarius luridus - Aegiceras curniculatum L & 0,806 & Asosiasi kuat \\
4. & Nassarius luridus - Aegiceras floridum R & 0,949 & Asosiasi kuat \\
5. & Nassarius luridus - Bruguiera sexangular & 0,806 & Asosiasi kuat \\
6. & Nassarius luridus - Bruguiera hainessi & 0,949 & Asosiasi kuat \\
7. & Nassarius luridus - Bruguiera palviflora & 0,837 & Asosiasi kuat \\
8. & Nassarius luridus - Rhizophora apiculate & 0,949 & Asosiasi kuat \\
9. & Nassarius luridus - Ceriops taga & 0,806 & Asosiasi kuat \\
10. & Nassarius luridus - Bruguiera exaristafa & 0,949 & Asosiasi kuat \\
\hline
\end{tabular}

Tabel 7. Kekuatan Asosiasi Jenis Mangrove Dan Gastropoda Di Perairan Pantai Desa Tiow Dan Desa Haria Berdasarkan Indeks Ochiai (OI).

\begin{tabular}{clcc}
\hline No & \multicolumn{1}{c}{ Pasangan Spesies } & OI & Keterangan \\
\hline 1. & Strombus urceus -Avicennia eucalyptifolia & 0,759 & Asosiasi kuat \\
2. & Strombus urceus - Avicennia lanata & 0,792 & Asosiasi kuat \\
3. & Strombus urceus - Aegiceras curniculatum L & 0,787 & Asosiasi kuat \\
4. & Strombus urceus - Aegiceras floridum R & 0,914 & Asosiasi kuat \\
5. & Strombus urceus - Bruguiera sexangular & 0,792 & Asosiasi kuat \\
6. & Strombus urceus - Bruguiera hainessi & 0,787 & Asosiasi kuat \\
7. & Strombus urceus - Bruguiera palviflora & 0,759 & Asosiasi kuat \\
8. & Strombus urceus - Rhizophora apiculate & 0,792 & Asosiasi kuat \\
9. & Strombus urceus - Ceriops taga & 0,914 & Asosiasi kuat \\
10. & Strombus urceus - Bruguiera exaristafa & 0,787 & Asosiasi kuat \\
\hline
\end{tabular}


Tabel 8. Kekuatan Asosiasi Jenis Mangrove Dan Gastropoda Di PerairanPantai Desa Tiow Dan Desa Haria Berdasarkan Indeks Ochiai (OI).

\begin{tabular}{clcc}
\hline No & \multicolumn{1}{c}{ Pasangan Spesies } & OI & Keterangan \\
\hline 1. & Cypraea annulu-Avicennia eucalyptifolia & 0,898 & Asosiasi kuat \\
2. & Cypraea annulu-Avicennia lanata & 0,853 & Asosiasi kuat \\
3. & Cypraea annulu-Aegiceras curniculatum L & 0,859 & Asosiasi kuat \\
4. & Cypraea annulu- Aegiceras floridum $R$ & 0,792 & Asosiasi kuat \\
5. & Cypraea annulu- Bruguiera sexangular & 0,898 & Asosiasi kuat \\
6. Cypraea annulu- Bruguiera hainessi & 0,853 & Asosiasi kuat \\
7. & Cypraea annulu- Bruguiera palviflora & 0,853 & Asosiasi kuat \\
8. & Cypraea annulu- Rhizophora apiculate & 0,898 & Asosiasi kuat \\
9. & Cypraea annulu- Ceriops taga & 0,898 & Asosiasi kuat \\
10. & Cypraea annulu-Bruguiera exaristafa & 0,853 & Asosiasi kuat \\
\hline
\end{tabular}

Tabel 9. Kekuatan Asosiasi Jenis Mangrove Dan Gastropoda Di PerairanPantai Desa Tiow Dan Desa Haria Berdasarkan Indeks Ochiai (OI).

\begin{tabular}{cccc} 
No & \multicolumn{1}{c}{ Pasangan Spesies } & OI & Keterangan \\
1. & Nerita squamulata -Avicennia eucalyptifolia & 0,779 & Asosiasi kuat \\
2. & Nerita squamulata - Avicennia lanata & 0,916 & Asosiasi kuat \\
3. & Nerita squamulata - Aegiceras curniculatum L & 0,789 & Asosiasi kuat \\
4. & Nerita squamulata - Aegiceras floridum R & 0,859 & Asosiasi kuat \\
5. & Nerita squamulata - Bruguiera sexangular & 0,786 & Asosiasi kuat \\
6. Nerita squamulata - Bruguiera hainessi & 0,757 & Asosiasi kuat \\
7. & Nerita squamulata - Bruguiera palviflora & 0,815 & Asosiasi kuat \\
8. Nerita squamulata - Rhizophora apiculate & 0,757 & Asosiasi kuat \\
9. & Nerita squamulata - Ceriops taga & 0,741 & Asosiasi kuat \\
10. Nerita squamulata - Bruguiera exaristafa & 0,719 & Asosiasi kuat
\end{tabular}

Gambar 2. Grafik Komposisi Jenis Mangrove di Perairan Pantai Desa Tiouw dan Desa Haria.

Jumlah individu spesies mangrove yang ditemukan

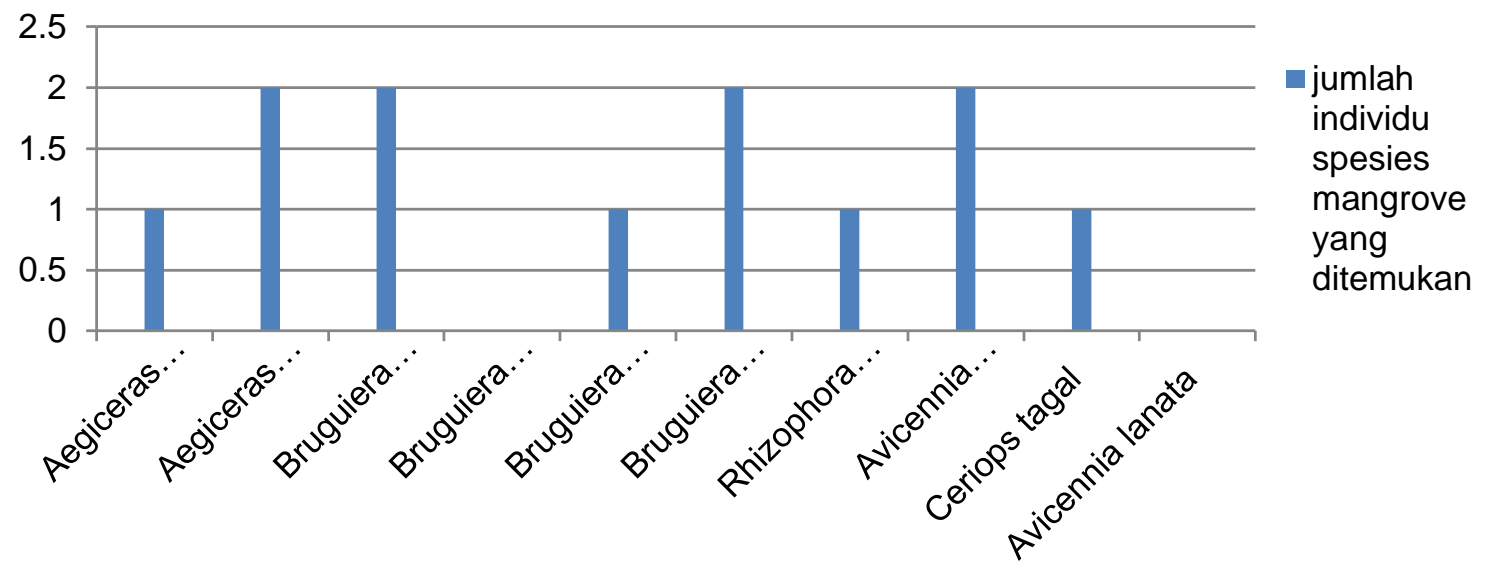

Gambar 3. Grafik Komposisi Jenis Gastropoda Yang Ditemukan Di perairan Pantai Desa Tiouw Dan Haria. 


\section{Jumlah Individu Spesies Gastropoda}

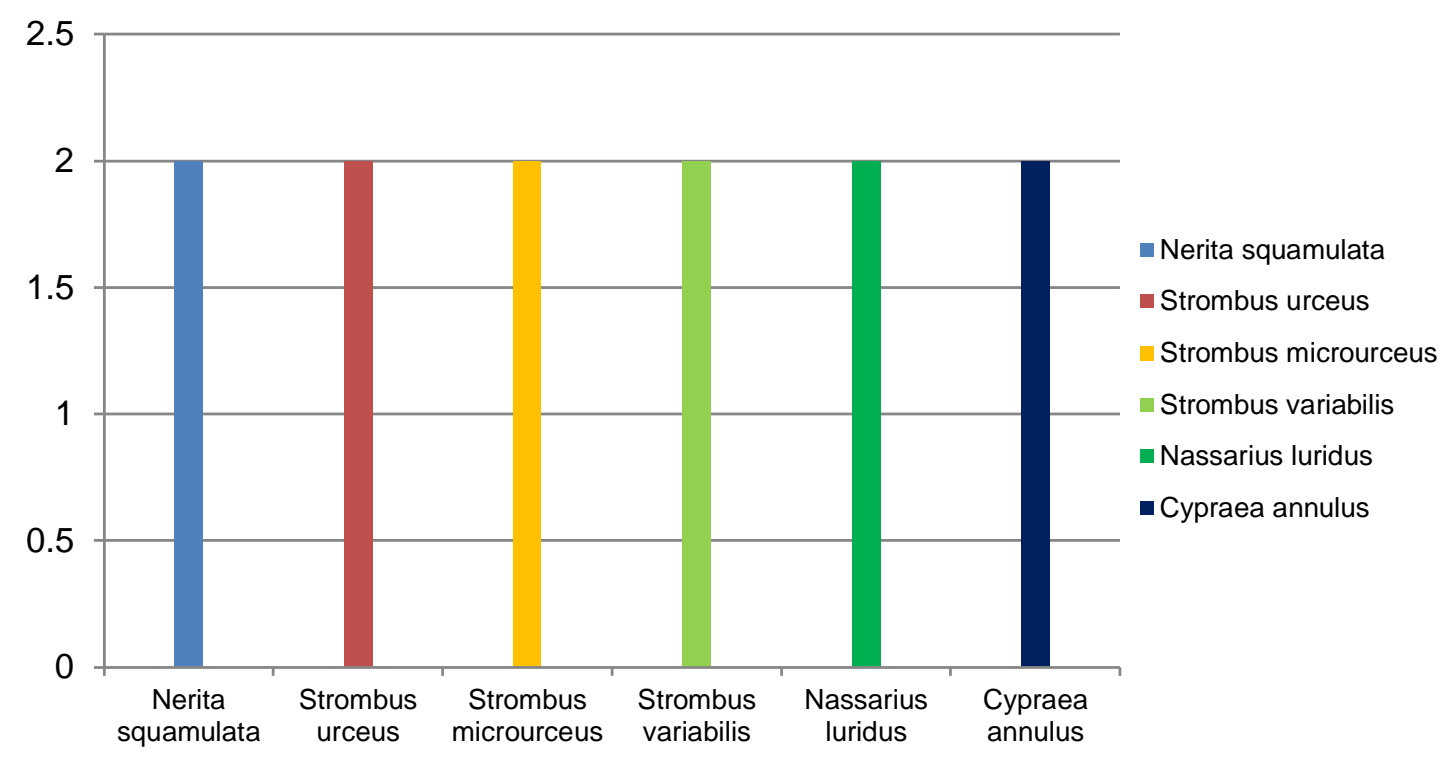

Asosiasi gastropoda dengan mangrove di perairan pantai desa tiouw dan desa haria. Seperti yang di ketahui, asosiasi yang terjadi antara gastropoda dengan mangrove di perairan pantai desa tiouw dan haria yaitu dilihat dari hasil penelitian dalam mengumpulkan data dan dokumentasi. Gastropoda yang di temukan dan diambil yaitu yang menempel pada tumbuhan mangrove, baik di akar, batang pohon dan bahkan ada yang terdapat di dedaunan mangrove. Di ambil dan di identifikasi masing-masing jenisnya.

Faktor-faktor lingkungan yang diukur meliputi: Suhu, $\mathrm{pH}$ dan Salinitas. kisaran rata-rata nilai suhu perairan $36^{\circ} \mathrm{C}$, kisaran rata-rata nilai salinitas $31 \%$, yang masih ideal untuk pertumbuhan mangrove dan gastropoda, Nilai derajat keasaman $(\mathrm{pH})$ di lokasi pengamatan kisaran rata-rata yaitu 7 .

Tipe substrat pada ekosistem mangrove di perairan pantai negeri tiouw sebagian besar terdiri dari pasir berlumpur, patahan karang mati. Menurut Nybakken (1992), umumnya mangrove tumbuh pada semua tipe substrat, mulai dari lumpur lunak sampai batu granit, tetapi paling banyak menepati substrat berjenis lunak yang kaya material organik, sehingga mendukung kehidupan gastropoda sebagai filter feeder.

Penelitian ini melibatkan 2 stasiun penelitian yang berlokasi di Desa Tiouw dan Haria. Dari pengamatan yang dilakukan pada lokasi penelitian ditemukan 4 jenis mangrove pada perairan pantai Desa Tiouw, dibandingkan dengan perairan pantai Desa Haria yang jumlah spesies ditemukan berjumlah 8 .

\section{KESIMPULAN}

1. Faktor-faktor lingkungan yang diukur meliputi: Suhu, pH dan Salinitas. kisaran rata-rata nilai suhu perairan $36^{\circ} \mathrm{C}$, kisaran rata-rata nilai salinitas $31 \%$, yang masih ideal untuk pertumbuhan mangrove dan gastropoda, Nilai derajat keasaman $(\mathrm{pH})$ di lokasi pengamatan kisaran ratarata yaitu 7 .

2. Jenis mangrove yang ada di Perairan Pantai Desa Tiouw dan Haria: pada stasiun I di perairan pantai Desa Tiouw, temuan spesies mangrove lebih sedikit dengan jumlah 4 spesies, dibandingkan dengan stasiun II diperairan pantai Desa Haria temuan spesies mangrove 
tergolong banyak dengan jumlah spesies 8.

3. Jenis Gastropoda yang ada di Perairan Pantai Desa Tiouw dan Haria: dilihat bahwa rata-rata terdapat 6 jenis gastropoda yang menempel pada mangrove ditemukan pada perairan pantai Desa Tiouw dan Haria.

4. Asosiasi antara mangrove dengan Gastropoda di Perairan Pantai Desa Tiouw dan Haria: hasil penelitian ditemukan bahwa terdapat nilai asosiasi setiap spesies yang tak jauh berbeda nilainya berbeda pada kedua stasiun baik diperairan pantai Desa Tiouw dan perairan pantai Desa Haria.

\section{DAFTAR PUSTAKA}

Dharma, B. 1988. Siput dan Kerang Indonesia. PT Sarana Graha. Jakarta.

Ludwig, J. A. dan J. F. Reynolds. 1988. Statistical Ecology, a Primer on Methods and Computing. John Willey and Sons. New York.

Mueller-Dombois, D. dan $H$. Ellenberg. 1974. Aims and Methods of Vegetation Ecology. New York University

Nyabakken, J. W, 1992. Biologi Laut SuatuPendekatanEkologis. Jakarta: Gramedia

Rochana, E. 2006. Ekosistem Mangrove dan Pengelolaannya di Indonesia. Yokyakarta www.irwantoshut.

Supriharyono, 2000 . Pelestarian dan Pengelolaan Sumber Daya Alam di Wilayah Pesisir Tropis. Jakarta: Gramedia

Saripantung, 2013. Mangrove. Diskusi panel Prodi Biologi Konservasi FMPIAUI. Depok.

Suwondo, Febrita, E., Dessy dan Alpusari, M. 2004. Kualitas Biologi Perairan Sungai Senapelan, Sago dan Sail di Kota Pekan Baru Bioindikator Plangton dan Bentos. Biogenesis, 1 (1): 15-20.

Whittaker R.H, 1975. Communities and ekosistem. MacMillan Publishing Co. INC. New York

Yuniarti, N., Nugroho, A.E., Hakim, L., Supardjan, dan Istyastono, E.P., 2007, Aktivitas Antioksidan Senyawa Gamavuton dan Turunannya, Artocarpus 7(2): 70-81. 